\title{
Kártyatrükk: Az Európai Bíróság C-228/18. sz. Budapest Bank ügyben hozott ítélete és annak jelentősége
}

\section{Card Trick: The Judgment of the Court of Justice of the European Union in the Budapest Bank Case (C-228/18)}

Az Európai Bíróság előtt a magyar Kúria által kezdeményezett előzetes döntéshozatal iránti kérelem az európai versenyjog egyik sokat vitatott kulcskérdését vetette fel: mikor tekinthető egy magatartás versenykorlátozó célúnak.

A jelen tanulmány célja, hogy az elözetes döntéshozatalhoz vezető elôzmények rövid felvázolása után áttekintse az Európai Bíróság ítéletének föbb megállapitásait. Ezt követően bemutatja, hogyan illeszkedik az ítélet a versenykorlátozó célzat megállapításával kapcsolatos európai döntéshozatali gyakorlatba, illetve hogy miben és mennyiben fejleszti azt tovább. A tanulmány az itéletnek az európai versenyjog érvényesitésére gyakorolt lehetséges következményeivel kapcsolatos megállapitásokkal zárul.

A tanulmány fö következtetése, hogy az ítélet a Cartes Bancaires és azt követö esetjog vonalába illeszkedik, ugyanakkor túl is mutat azon, azáltal, hogy még tovább erôsiti a cél szerinti versenykorlátozás megállapíthatóságának kivételes jellegét.

A szerző véleménye szerint a versenyhatóságok beavatkozási mozgásterének az itélet miatti szükülése hozzájárulhat ahhoz, hogy az új típusú versenykorlátozásokelemzése kapcsán feltehetöleg kénytelenek lesznek eszköztárukat újraértelmezni, illetve új eszközöket találni a versenyjogi beavatkozás hatékonyságának megörzése érdekében.

Kulcsszavak: bankközi jutalék, MIF, kártyarendszer, versenykorlátozó cél, versenykorlátozó hatás, megállapodások, kétoldalú piacok, platform 
The preliminary ruling initiated by the Hungarian Supreme Court before the European Court of Justice raised one of the most controversial key issues of European competition law: when can a conduct be considered restrictive of competition by object.

The purpose of this study is to review the main findings of the judgment of the CJEU after briefly outlining the background to the preliminary ruling. It then sets out how the judgment fits into European decision-making practice on the establishment of an anti-competitive object and how and to what extent it further develops it. The study concludes with findings on the possible consequences of the judgment for the enforcement of European competition law.

The main conclusion of the study is that the judgment is in line with the Cartes Bancaires line of case law, but it also further develops that line of case law in a way that it reinforces the exceptional nature of finding a conduct to be restrictive of competition by object.

According to the author, the narrowing of the discretion of competition authorities due to the judgment contributes to the fact that they will presumably be forced to reinterpret their tools and find new tools to preserve the effectiveness of competition intervention in the analysis of new types of competition restrictions.

Keywords: interchange fee, MIF, payment card system, restriction by object, restriction by effect, agreements, two-sided markets, platform

\section{Bevezetés}

Az Európai Unió Bírósága (EUB vagy Bíróság) 2020. április 2-án hozott ítéletet egy magyar vonatkozású, a Kúria által előterjesztett előzetes döntéshozatali kérelem tárgyában. ${ }^{1}$

Az alapügy a Gazdasági Versenyhivatalnak egy 2009-ben hozott határozatát érinti, amelyben a MasterCard és Visa kártyatársaságok és a magyar bankok által kötött, a bankkártyákkal kapcsolatos megállapodás kapcsán marasztalta el az eljárás alá vont vállalkozásokat.

Az ügy kontextusához tartozik, hogy az alapügyben érintett bankközi jutalékok versenyjogi megfelelésének kérdése az Európai Bizottság és az EU-tagállamok

Az EUB C-228/18. sz. Budapest Bank ügyben 2020. április 2-án hozott ítélete [EU:C:2020:265] (Budapest Bank ítélet). Ebben a vonatkozásban érdekes megemlíteni, hogy szintén a Kúria által előterjesztett előzetes döntéshozatali kérelem eredménye az Allianz Hungária ügyben hozott ítélet (Az EUB C-32/11 sz. Allianz Hungária Biztosító Zrt és társai kontra Gazdasági Versenyhivatal ügyben 2013. március 14-én hozott ítélete [ECLI:EU:C:2013:160], amelyben az EUB első esetben emelte be a hatás szerinti elemzés elemeit a cél szerinti versenykorlátozás megállapításának vizsgálati körébe. 
versenyhatóságai, illetve bíróságai előtti ügyekben folyamatosan napirenden volt az elmúlt évtizedben (lásd erről részletesebben a 3.3 pontot). ${ }^{2}$

A szerző hipotézise szerint a Bíróság ítéletének viszont ezen az iparágon túlmutató jelentősége van abban a tekintetben, hogy versenyjogi alapfogalmakat tárgyal, ugyanis a cél és hatás szerinti versenykorlátozás fogalmát feszegeti és fejleszti tovább, igaz egy kétoldalú piac kontextusában.

Az ítélet jelentősége elsősorban abban áll, hogy kijelöli a versenyjogi jogérvényesítés kereteit, határait. Ebben a tekintetben a szerző véleménye szerint meglehetősen magasra teszi a mércét a versenyhatóságok, ideértve az Európai Bizottságot is, és a bíróságok számára, jelentősen megnehezítve ezzel az új típusú jogsértések esetén a cél szerinti versenykorlátozó jelleg megállapítását. A hatás alapú vizsgálat körülményes és hosszú időt vesz igénybe, ezért az ítélet következménye az lehet, hogy szembekerülve a minél gyorsabb beavatkozás társadalmi és politikai igényével, illetve az új típusú online/internetes piacokon feltételezhetően versenyellenes magatartásokkal, a versenyhatóságok új típusú eszközöket keresnek a hatékony beavatkozás érdekében. Ennek jelei láthatók például abban, hogy az Európai Bizottság olyan új típusú eszközökhöz nyúl, mint például az eddig nem használt ideiglenes intézkedések, ${ }^{3}$ illetve egy új ex-ante versenyfelügyeleti eszköz bevezetése. ${ }^{4}$

Eltekintve a versenyjogi jogérvényesítésre gyakorolt negatív hatástól, a szerző véleménye szerint az ítélet jogi szempontból is kifogásolható, mert olyan új szempontokat vezet be a cél szerinti jogsértések értékelésébe, amelyek elmossák a cél és hatás szerinti jogsértés közötti különbséget. Ráadásul a bevezetett új elemek alkalmazásával kapcsolatban a Bíróság nem ad részletes útmutatást, illetve azt sem magyarázza meg ítéletében, hogy miért indokolt eltérni az árrögzítésre vonatkozó korábbi esetjogtól. Kérdéses, hogy ez a bírói jogalkotás mennyiben szolgálja a jogbiztonságot, ugyanis az ítélet több kérdést vet föl, mint amennyit megoldani kíván.

Továbbá, mivel a bankkártya-elfogadás piaca kétoldalú piac, az ítéletnek jelentősége lehet abban a tekintetben is, hogy a kétoldalú digitális piacok esetében iránymutató lehet ez a megközelítés, ami kijelöli - a manapság jelentős aktualitású - az online platformok versenyjogi kezelésének lehetséges irányvonalait.

A következőkben először az alapügyet és a kártyaelfogadási piac alapjellemzőit mutatjuk be, majd ezt követően elemezzük a főtanácsnoki indítványt és a Bíróság ítéletét, utána az idevágó legújabb bizottsági és tagállami eseteket, joggyakorlatot vesszük számba, végül pedig a Budapest Bank ítélet lehetséges következményeit villantjuk fel.

A tagállami ügyek közül talán az Egyesült Királyságbeli Sainsbury’s v MasterCard ügy volt a legjelentősebb, amely ráadásul az összes fellebviteli fórumot megjárta, és az érintett bíróságok részletesen foglalkoztak az MIF versenykorlátozó jellegének megállapítására vonatkozó elemzés minden apektusával, lásd: Sainsbury's Supermarkets Ltd (Respondent) v Visa Europe Services LLC and others (Appellants) Sainsbury's Supermarkets Ltd and others (Respondents) v Mastercard Incorporated and others (Appellants). 17 June 2020.

3 2019. október 16-án a Bizottság történelmében elöször egy antitrösztügyben ideiglenes intézkedés elrendelését jelentette be a Broadcom chipgyártó ellen (Case AT. 40608), hogy a verseny komoly és viszszafordíthatatlan torzítását megelőzze (Antitrust: Commission imposes interim measures on Broadcom in TV and modem chipset markets. European Commission, 2019.).

4 Ezt a Biztottság 2020. június 2-án jelentette be Antitrust: Commission consults stakeholders on a possible new competition tool. European Commission, 2020.

Európai Tükör 2020/3. 


\section{Elözmények - az alapügy}

\subsection{A Gazdasági Versenyhivatal határozata}

A Gazdasági Versenyhivatal 2009. szeptember 24-én kelt Vj-18/2008/341. számú határozatával (Határozat) megállapította, hogy az eljárás alá vont bankok, valamint a MasterCard és a Visa nemzetközi kártyatársaságok ${ }^{5}$ versenykorlátozó megállapodást kötöttek azzal, hogy kártyáikra és minden bankra egységesen alkalmazandó bankközi jutalék mértéket és struktúrát határoztak meg, illetve hogy az ilyen megállapodáshoz szabályzataikkal keretet biztosítottak, és azt támogatták. A versenykorlátozó magatartás időtartama 1997. január 1-jétől (egyes vállalkozások később csatlakoztak) 2008. július 30-ig terjedt. A Határozat szerint az eljárás alá vont vállalkozások e magatartásukkal, célja és hatása szerint is megsértették a tisztességtelen piaci magatartás és a versenykorlátozás tilalmáról szóló 1996. évi LVII. törvény 11. §-ának (1) bekezdését, valamint 2004. május 1-jétől 2008. július 30-ig az Európai Közösséget létrehozó Szerződés 81. cikk (1) bekezdését [jelenleg az EUMSz 101. cikk (1) bekezdése]. A jogsértés miatt a Gazdasági Versenyhivatal az eljárás alá vont vállalkozásokat bírságokkal sújtotta, összesen 1922000000 Ft értékben.

\subsubsection{A kártyás fizetési rendszer mint kétoldalú iparág és a bankközi jutalék szerepe}

A feltételezett versenykorlátozás, a Határozat, illetve az ezt követő jogvita és az EUB ítéletének megértéséhez szükséges röviden felvázolni a kártyás fizetési rendszerek múködésének alapvető jellemzőit és a bankközi jutaléknak ebben játszott szerepét.

A kártyás fizetési rendszerekben nagyszámú kártyabirtokos és az adott kártyarendszer (ebben az esetben a MasterCard es a Visa) kártyáját elfogadó kereskedő vesz részt. A különféle típusú kártyák mind a vásárlók (kártyabirtokosok), mind a kereskedők oldalán egyfajta fizetési eszközként jelentkeznek. A kártyabirtokos a kibocsátó banktól szerzi be a kártyáját (tipikusan attól, amelyik a folyószámláját vezeti). A kereskedők az elfogadó bank közremúködése révén képesek elfogadni a kártyás fizetést. A kártyát elfogadó kereskedő vagy az elfogadó bank, vagy a saját tulajdonában, illetve működtetésében levő POS- (Point of Sale) terminált használ e célból. Mind a kibocsátó, mind az elfogadó bank különféle módon és jogcímeken jut díjbevételhez ügyfeleitôl. A rendszert múködtetô kártyatársaság a kibocsátó és elfogadó bankoktól tesz szert díjbevételekre, miközben szerződéses kapcsolatban sem a kereskedőkkel, sem a kártyabirtokosokkal nem áll.

A Határozat szerint a bankkártyás fizetési rendszer kétoldalú iparágként jellemezhető. Az ilyen kétoldalú piac esetében a piac egyik oldalának árazási döntései befolyásolják a kapcsolódó piac keresleti viszonyait, ami viszont visszahat az eredeti piac keresletére. A tapasztalat azt mutatja, hogy a bankkártyás fizetési rendszerekben a két oldalon bizonyos árazás/díjak meghatározása által növelhető a tranzakciók száma. Ennek oka

https://gvh.hu/data/cms992218/Vj018-2008_m.pdf (A letöltés dátuma: 2020. 08. 09.)

Európai Tükör 2020/3. 
elsősorban, hogy a két piaci oldal között keresztirányú pozitív externáliák hatnak: egyrészt egy kártyabirtokos akkor ítéli hasznosnak a bankkártyát, ha azt a kereskedők széles körben fogadják el, másrészt egy kereskedő hajlandósága a kártya elfogadására megnő, ha a vásárlók nagyobb része használja a kártyát, vagyis mindkét oldal számára vonzóbb a szolgáltatás, ha „a másik oldalon” nő a használók száma. A két oldal keresletének befolyásolását szolgálhatja a bankközi jutalék. ${ }^{6}$

A bankközi jutalék természetének megértéséhez azt szükséges tudni, hogy a MasterCard és Visa rendszere úgynevezett négyszereplős kártyarendszer.

A négyszereplős kártyarendszer résztvevői a bankkártyával történő fizetést kezdeményező kártyabirtokos, valamint a kártyát elfogadó kereskedő. A kártyaelfogadást a kereskedő részére a bankkártya-elfogadást nyújtó szolgáltató (jellemzően bank vagy specializált fizetési szolgáltató) végzi, míg a kártyát a kártyabirtokosnak a bankkártyát kibocsátó szolgáltató biztosítja. További közremúködőként a fizetés folyamatában a tranzakció lebonyolításához szükséges platformot biztosító kártyatársaság is megjelenik.

A kereskedő a kártyaelfogadásért kereskedői díjat fizet a kártyaelfogadónak, amely általában a tranzakció bizonyos százalékában meghatározott összeg. A kereskedői díj jellemzően három díjelemből tevődik össze, a kereskedői jutalékból, rendszerdíjból és bankközi jutalékból (ez utóbbi angolul interchange fee vagy a továbbiakban: IF).

A kereskedői díj elemei közül a kereskedői jutalék lényegében a kártyaelfogadási szolgáltatás ellenértéke, az elfogadást nyújtó pénzügyi szolgáltató ezt tartja meg, viszont a kártyatársaságok szabályzatai szerint a rendszerdíjat a kártyatársaságok felé, a bankközi jutalékot pedig a bankkártya-kibocsátók felé továbbítja.

A jelen ügyben központi szerepet játszó bankközi jutalékot általában a kártyatársaság vagy az egyes országokban müködő kártyatársasági tagok határozzák meg, jellemzően az egyes tranzakciók meghatározott százalékában. A bankközi jutalék azon formája, amikor annak mértékét a bankok többoldalú megállapodással határozzák meg a multilateral interchange fee vagy röviden MIF, elhatárolandó a kétoldalú bankközi jutaléktól (amikor azt két bank kétoldalú megállapodásban rendezi).

A bankközi jutalék meghatározásának módja eltérő lehet kártyatársaságonként és országonként is, azt meghatározhatja egy országra nézve az adott kártyatársaság vagy a kártyatársaságnak az adott országban működő tagjai/licencjogosultjai is. ${ }^{\text {? }}$

\subsubsection{A bankközi jutalék meghatározása Magyarországon}

A Határozatban jogsértőként azonosított magatartás előzményei az 1990-es évek elejére nyúlnak vissza. Ekkor Magyarországon a hitelkártyafizetési rendszer fejlődése még kezdeti szakaszában volt. 1991 és 1994 között, amíg csak néhány bank vett részt Magyarországon a hitelkártyarendszerben, a bankok kétoldalúan állapodtak meg a bankközi jutalék mértékében. A VISA azonban már 1994ben felhívta a magyarországi tagbankokat olyan VISA Nemzeti Fórum létrehozására, amelynek egyik feladata a helyi árpolitika

Lásd különösen a Határozat II.2.2. pontját.

Lásd a Határozat 23. pontját.

Európai Tükör 2020/3. 
kialakítása (ársávok kialakítása az IF vonatkozásában) volt. 1995 és 1996 folyamán a kártyaüzletágba bekapcsolódó bankok multilaterális együttmúködést alakítottak ki (Fórum), amelynek keretében esetenkénti megbeszéléseken vitatták meg a kártyaüzletág együttműködést igénylő különböző kérdéseit.

A Fórum keretében hét bank, amelyek többsége mindkét kártyatársaság hitelkártyarendszeréhez csatlakozott, 1996. április 24-én megállapodást fogadott el az egységes kereskedői díj (MSC) minimális mértékére vonatkozóan (MSC-megállapodás). Az MSC-megállapodás végül azonban soha nem lépett hatályba. 1996. augusztus 28-án ugyanez a bankcsoport elfogadta azt a megállapodást, amelyben egységesen szabályozták a két kártyatársaság különböző tranzakciókhoz kapcsolódó bankközi jutalék díjainak mértékét 1996. október 1-jei hatállyal (MIF-megállapodás). A MIF-megállapodásról szóló ülésen a kártyatársaságok képviselői nem vettek részt, azonban a Kereskedelmi és Hitelbank Zrt. kapcsolattartó bankként a megállapodásról készült másolatot küldött nekik. Ezt követően további bankok csatlakoztak a MIF-megállapodáshoz és a Fórumhoz.

A Gazdasági Versenyhivatal (GVH) 2008. január 31-én a MIF-megállapodással kapcsolatban versenyfelügyeleti eljárást indított. A megállapodás 2008. július 30-ig volt hatályban.

\subsubsection{A GVH által megállapított jogsértés}

A Fórum keretében egységesen megállapított bankközi jutalékokat a GVH megállapodásként definiálta, amelyben a megállapodást megkötő hét pénzintézet és a kártyás fizetés piacára később belépő bankok, valamint a Visa és a MasterCard vettek részt. ${ }^{8}$

A Versenytanács megállapította, hogy a vizsgált megállapodás egységesen állapította meg a bankközi jutalék mértékét, és annak közös és egységes megállapítása torzította a versenyt. Álláspontja szerint a megállapodás kiküszöbölte a Visa és MasterCard közötti versenyt, és egyben szükségszerủen korlátozta az elfogadó bankok közötti versenyt is. A megállapodás ugyanis közvetetten befolyásolta a kereskedői díj szintjét, ami az elfogadói oldalon a piaci verseny egyik legfontosabb tényezője, ugyanakkor mivel az MIF-ből a kibocsátó bankok is részesedtek, a kibocsátói piacot is érintette a megállapodás.

A Versenytanács a vizsgált megállapodást versenykorlátozó célzatúnak minősítette, mert (i) a két kártyatársaság együttes kezelése a két társaság közötti árverseny egyik legfontosabb elemét semlegesítette, (ii) maguk az eljárás alá vont hitelintézetek is az elfogadó bankok közötti díjversenyt mérséklő szerepet tulajdonítottak neki, valamint (iii) ezektől függetlenül is a bankközi jutalék kártyatársaságok szintjén megvalósult együttes megállapítása olyan természetủ megállapodás, amely szükségszerúen kihat a kereskedői díj téren az elfogadó bankok közötti versenyre. ${ }^{9}$ A Versenytanács figyelembe vette azt is, hogy az eljárás alá vontak szándéka az egymás közötti verseny mederben tartása volt.

Lásd a Határozat VI.2. pontját.

Lásd a Határozat VI.3.3. pontját.

Európai Tükör 2020/3. 
Ugyanakkor a Versenytanács szerint az MIF-megállapodás versenykorlátozó hatásúnak is minősül, mert az elfogadói szolgáltatások piacán az elfogadó bankok közötti árverseny korlátozásához vezetett, illetve káros versenyhatása volt az is, hogy annak eredményeképpen a pénzintézetek egységesen kezelték mindkét kártyatársaság kártyáit, torzítva ezzel a bankközi jutalékokat, a kereskedői díjakat és a kibocsátói versenyt. Ezen túl az MIF-megállapodás korlátozta a bankkártyás fizetési rendszerek közötti versenyt is. ${ }^{10}$

\subsection{A magyar bírósági eljárás}

\subsubsection{A Fővárosi Közigazgatási és Munkaügyi Bíróság ítélete}

A Határozat ellen az érintettek felülvizsgálati kérelemmel éltek, amelyet a Fővárosi Közigazgatási és Munkaügyi Bíróság 2016. január 11-én kelt, 30.K.33.520/214/78. számú ítéletével elutasított. ${ }^{11}$

Az elsőfokú bíróság rögzítette, hogy a felperesek közti megállapodással a multilaterális bankközi jutalék mesterséges koordinációjára került sor, amely szükségszerűen korlátozza a versengő magatartást, amely hosszabb távon a fogyasztói jólét záloga. Az MIF díjfelhajtó hatásával kapcsolatban rögzítette, hogy nem az ár, díj szokásos mozgásának az iránya a döntő, hanem a versenyben betöltött szerepe, így az MIF rögzítése szükségszerűen káros a versenyre, mint a „szokásos” árrögzítés. A mentesüléssel összefüggésben kiemelte a bíróság, hogy a felpereseknek meggyőzően, a vizsgált időszak egészére kellett volna igazolni, hogy a korlátozás szükséges, a vele járó esetleges előnyök nagyobbak a hátrányoknál, és hogy a haszon méltányos része eljut a fogyasztókhoz.

\subsubsection{A Fővárosi Törvényszék ítélete}

Az I-VII. rendű felperesek fellebbezése nyomán eljárt Fővárosi Törvényszék az elsőfokú bíróság ítéletét hatályon kívül helyezte, és a GVH-t új eljárás lefolytatására kötelezte.

A Fővárosi Törvényszék új eljárásra kötelező rendelkezése szerint a megismételt versenyfelügyeleti eljárásban azt kell vizsgálni, hogy a pénzintézetek azzal a magatartásukkal, hogy egységes bankközi jutalék mértéket, struktúrát határoztak meg, továbbá a kártyatársaságok azzal, hogy ehhez szabályzataikkal keretet biztosítottak, és azt támogatták versenykorlátozó hatású megállapodást kötöttek-e. A Fővárosi Törvényszék

Lásd a Határozat VI.3.4. pontját.

Az elsőfokú bíróság a per tárgyalását 2010. október 29-én az Európai Unió Törvényszéke előtt T-111/08. számon a MasterCard és az Európai Bizottság között folyamatban lévő eljárás jogerős befejezéséig felfüggesztette. A bíróság a per tárgyalásának felfüggesztését a Törvényszék 2010. május 24-i ítéletét követően is fenntartotta, tekintettel arra, hogy a Törvényszék T-111/08. számú ítélete elleni fellebbezés folytán az eljárás az az Európai Unó Bírósága előtt C-382/12. számon folytatódott. Ez utóbbi perben 2014. szeptember 11-én született ítélet, az elsőfokú bírósági eljárás ezt követően folytatódott. 
azon az alapon találta jogsértőnek és azért helyezte hatályon kívül, új eljárásra utasítva a GVH határozatát, mivel - ellentétben az elsőfokú bíróság értékelésével - megítélése szerint a Határozatban feltárt tényállás alapján a magatartás cél szerint, azaz természeténél fogva versenykorlátozó jellege nem állt fenn, a magatartás hatásában versenykorlátozó jellegét pedig a feltárt tényállás és a rendelkezésre álló bizonyítékok alapján nem találta bizonyítottnak.

\subsubsection{A Kúria végzése}

A Fővárosi Törvényszék ítéletével szemben az alperes Gazdasági Versenyhivatal élt felülvizsgálati kérelemmel. A felperesek felülvizsgálati ellenkérelmet terjesztettek elő. A Kúria az előtte folyamatban lévő per felfüggesztéséről döntött, és az EUB előtt előzetes döntéshozatali eljárást kezdeményezett. ${ }^{12} \mathrm{~A}$ Kúria a következő négy kérdést tette fel a Bíróságnak:

„1) Értelmezhető-e az [EKSZ 81. cikk] (1) bekezdése [az EUMSZ 101. cikk (1) bekezdése] úgy, hogy ugyanazon magatartás egyaránt sértheti a versenykorlátozó cél és a versenykorlátozó hatás, mint önálló jogalapok alapján az EKSZ 81. cikk (1) bekezdésében [EUMSZ 101. cikk (1) bekezdésében] foglalt rendelkezéseket?

2) Értelmezhető-e az [EKSZ 81. cikk] (1) bekezdése [az EUMSZ 101. cikk (1) bekezdése] úgy, hogy céljánál fogva versenykorlátozó az ügy tárgya szerinti, magyarországi tagbankok közötti megállapodás, amely a Mastercard és a Visa kártyatársaságok kártyáinak használatáért járó, kibocsátó bankokat megillető bankközi jutalékot mindkét kártyatársaságra nézve egységes mértékben határozta meg?

3) Értelmezhető-e az [EKSZ 81. cikk] (1) bekezdése [az EUMSZ 101. cikk (1) bekezdése] úgy, hogy a bankok közti megállapodásnak részesei azok a kártyatársaságok is, akik a megállapodás tartalmának kialakításában közvetlenül nem vettek részt, de a megállapodás elfogadását lehetővé tették, valamint a megállapodást elfogadták és alkalmazták, avagy ezt úgy kell értékelni, hogy a megállapodást kötő bankokkal összehangolták magatartásukat?

4) Értelmezhető-e az [EKSZ 81. cikk] (1) bekezdése [jelenleg az EUMSZ 101. cikk (1) bekezdése] úgy, hogy a versenyjogsértés megállapításához nem szükséges az ügy tárgyára figyelemmel annak elkülönítése, hogy a megállapodásban való részvételről, vagy a megállapodásban résztvevő bankok magatartásával való összehangolásról van-e szó?"13

C-228/18-1. számú irat.

13 Budapest Bank ítélet [EU:C:2020:265] 25. pontja.

Európai Tükör 2020/3. 


\section{Az Európai Unió Bíróságának eljárása - elözetes döntéshozatali kérelem}

\subsection{A Fötanácsnoki indítvány}

Michal Bobek főtanácsnok 2019 szeptemberében közzétett indítványában (Főtanácsnoki indítvány) az ügy kritikus pontjának a második kérdést tartotta, álláspontja szerint a többi kérdésre adandó válaszok viszonylag egyértelműek. ${ }^{14}$

\subsubsection{Az első kérdés}

Az első kérdéssel kapcsolatban elemzésének kiindulópontja, hogy az EUMSZ 101. cikk (1) bekezdését nagyon tágan fogalmazták meg, célja a vállalkozások közötti összejátszás bármilyen formájának a szabályozása. Rögzíti, hogy a cél által versenyellenes és hatás által versenyellenes megállapodások érdemben nem különböznek, mindkettő versenykorlátozó jellegű. A két fogalom közötti különbségtétel inkább eljárásjogi jelentőségű, azt jelöli ki, hogy a versenyhatóságoknak milyen típusú vizsgálatot kell lefolytatniuk az értékelés során. Mint ahogyan ez a Bíróság esetjogából kitűnik a cél/hatás megkülönböztetés azt jelenti, hogy a versenyhatóság elemzése elvégzése során nem köteles a megállapodás hatásaival kapcsolatos teljes körű vizsgálat elvégzésére, ha megállapítható és bizonyítható, hogy az cél által jogellenes. Ez azonban a főtanácsnok szerint nem zárja ki azt, hogy a hatóság egy konkrét ügyben valamely megállapodást célja és hatása szerint is megvizsgáljon, és megállapítsa, hogy az célja és hatása szerint is versenyellenes, amennyiben a korlátozás mindkét típusát a megfelelő bizonyítékokkal és értékeléssel támasztja alá. Végül az előterjesztő Bíróság ez irányú kételyeivel kapcsolatban kiemelte azt is, hogy ennek nem akadálya, hogy a versenyhatóság ugyanazokra a tényekre hivatkozik, továbbá, hogy nincs automatikus összefüggés a megállapodás cél vagy hatás által korlátozóként való minősítése és a kiszabható bírságok között, illetve az EUMSZ 101. cikk (3) bekezdése szerinti mentesülés alkalmazásának a lehetőségére. ${ }^{15}$

\subsubsection{A második kérdés}

A főtanácsnok a második kérdésnek szentelte a legtöbb figyelmet, indítványának nagy része ezt tárgyalja. Elemzésének kezdetén rögzíti, hogy véleménye szerint a feltett kérdést a Bíróság konkrétan nem fogja tudni megválaszolni, mert annak eldöntéséhez csak az előterjesztő bírság rendelkezik elég információval és szakértelemmel. Így indítványában a kérdés megválaszolásával kapcsolatos iránymutatást és szempontokat javasol.

\footnotetext{
14 Michal Bobek főtanácsnok C228/18. sz. ügy kapcsán 2019. szeptember 5-én ismertetett indítványa, [EU:C:2019:678].

15 A Főtanácsnoki indítvány [EU:C:2019:678] 18-36. pontjai.
}

Európai Tükör 2020/3. 
Először is a cél általi korlátozások fogalmát illetően ismerteti, hogy a Bíróság szerint ezt megszorítóan kell értelmezni, és az csak olyan egyeztetésekre alkalmazható, amelyek elegendő károssági fokot mutatnak. Álláspontja szerint az ítélkezési gyakorlatból e tekintetben kétlépcsős elemzés következik.

$\mathrm{Az}$ első lépésben az eljáró versenyhatóságnak a megállapodás tartalmát és az általa elérni kívánt célkitûzéseket kell vizsgálnia, hogy az a megállapodások azon csoportjába tartozik-e, amelynek ártalmas jellege a tapasztalat tükrében általánosan elfogadott és könnyen felfedhető. A szükséges tapasztalat fogalmát illetően hivatkozik Wahl főtanácsnoknak a Cartes Bancaires ügyben kifejtett álláspontjára, miszerint az úgy értelmezendő, mint „ami hagyományosan kitűnik a gazdasági elemzésből, ahogy azt a versenyhatóságok elismerték, illetve ahogy adott esetben az ítélkezési gyakorlat is jóváhagyta”.

A második lépésben javaslata szerint a hatóságoknak ellenőriznie kellene, hogy a versenyellenes megállapítást nem kérdőjelezik-e meg a jogi és gazdasági háttérrel összefüggő megfontolások. Ezenfelül a felek szándéka is figyelembe vehető. A második lépcsős elemzés intenzitásával kapcsolatban kifejti, hogy álláspontja szerint ez azt jelenti, hogy a versenyhatóságoknak a rendelkezésre álló bizonyítékok alapján kell ellenőriznie, hogy „nem állnak-e fenn olyan sajátos körülmények, amelyek a kérdéses megállapodás vélelmezett káros jellegét illetően kétségeket ébreszthetnek”. A főtanácsnok a vizsgálat menetét egy metaforával a következőként összegzi: „[H]a valami úgy néz ki, mint egy hal, és a szaga is olyan, mint a halnak, feltételezhetjük, hogy az egy hal. Hacsak első látásra nincs valami szokatlan ennél a vizsgált halnál - például nincs uszonya, a levegőben lebeg, vagy illatos, mint a liliom -, nem szükséges e hal részletesebb vizsgálata ahhoz, hogy azt halnak minősítsük. Ha azonban van valami, a szokásostól eltérő a kérdéses hal esetében, még besorolható halként, de csak a kérdéses élőlény részletes vizsgálatát követően." ${ }^{16}$

A vizsgálat fogalmi kereteinek tisztázását követően a főtanácsnok rátér a konkrét ügyben érintett megállapodás elemzésére. Megállapítja, hogy egy ilyen típusú, egységes bankközi jutalékot rögzítő megállapodás sem egy tipikus horizontális árrögzítő megállapodás, sem pedig egy viszonteladási árat rögzítő vertikális megállapodás. Így ezen megállapodás cél általi versenykorlátozó jellegének megállapításához, a fentiek szerinti elméleti keret értelmében, elöljáróban tisztázni kell az állítólagosan versenykorlátozó célú magatartást (felek, piacok, magatartás jellege és releváns időszak tekintetében). Ezt követően meg kell vizsgálni, hogy jelentős mértékű megbízható és szilárd jellegű tapasztalat áll-e rendelkezésre arra vonatkozón, hogy az ilyen magatartás lényege szerint versenyellenes, másodszor pedig, hogy a megállapodás jogi és gazdasági háttere miért nem kérdőjelezi meg a vélelmezett versenyellenes jelleget. ${ }^{17}$

A vizsgálat első pontjával, a jogsértő magatartás vizsgálatával kapcsolatban a főtanácsnok kifejti, hogy jelen ügyben az állítólagos jogsértés bizonyos aspektusai tekintetében valószínűsíthető ugyan a verseny bizonyos fokú korlátozása az érintett piacokon (bankközi szolgáltatások piaca, kereskedőknek nyújtott szolgáltatások downstream

A Főtanácsnoki indítvány 48. és 51. pontjai.

Uo. 53. és 54 pont.

Európai Tükör 2020/3. 
piaca, kártyatársaságok közötti upstream piac), kétségét fejezte ki azonban a tekintetben, hogy a kérdéses összefonódó piacok közötti kölcsönhatásokat megfelelően tisztázták-e. Hasonlóan megkérdőjelezte azt is, hogy a feltételezett jogsértés időbeli aspektusát kellően tisztázták, tekintettel arra, hogy az 12 évig volt érvényben. Következtetése szerint a több piacon aktív számos gazdasági szereplő részvételével együttjáró jelentős összetettség a fogalmi egyértelműség és pontosság szükségességét is növeli, illetve minél nagyobb a strukturális összetettség, annál kevésbé valószínűsíthető, hogy lehetséges egyértelmű cél általi korlátozásra következtetni. ${ }^{18}$

A vizsgálat második pontját, a jelentős mértékű megbízható és szilárd jellegű tapasztalatot illetően a főtanácsnok megkérdőjelezte az is, hogy az Európai Unió Törvényszékének és Bíróságának a MasterCard ügyben hozott ítéletei ${ }^{19}$ és a Bizottság gyakorlata kellően egyértelmú és egységes ebben a tekintetben, illetve kétséges, hogy néhány közigazgatási határozat, amely az egyeztetés hasonló formáira vonatkozik kellő tapasztalatnak minősülhet-e. Rámutatott továbbá arra, hogy más nemzeti hatóságok gyakorlata, illetve független szerzők által készített nemzetközi közgazdasági elveken, módszereken alapuló tanulmányokban kimutatható kellő mértékű egyetértés is hasznos lenne a szükséges tapasztalat igazolására. ${ }^{20}$

Végül a főtanácsnok azt vizsgálta meg, hogy a MIF-megállapodás jogi és gazdasági háttere megkérdőjelezi-e a vélelmezett versenyellenes jelleget. Ezzel kapcsolatban véleménye szerint azt a kérdést kell feltenni, hogy az adott ügy összefüggései mellett első látásra lehet-e észszerűen vitatni a megállapodás általában káros jellegével kapcsolatos felvetést. Álláspontja szerint, ha a MIF-megállapodásnak észszerűen lehettek hatásai, amelyek elősegítik a versenyt, és ha ezeket a pozitív hatásokat nem semlegesítették egyértelműen más versenyellenes hatások, akkor a megállapodás nem minősíthető a versenyt cél által korlátozónak. A mércét álláspontja szerint olyan ellentétes feltevésnek kellene képeznie, amely első látásra nem valószínútlen, és amely az adott ügy összefüggésében első látásra észszerűen kétségbe vonja az általános konvencionális ismeretet. Más szavakkal: álláspontja szerint, ha a megállapodásnak a lehetséges versenyt elősegítő oka nem zárható ki, úgy a megállapodás nem minősíthető cél szerinti korlátozásnak. ${ }^{21}$

A fentiek alapján a főtanácsnok nem kínál határozott és végleges választ az előterjesztett kérdésre, álláspontja szerint, a fenti szempontok figyelembevételével az előterjesztő bíróság feladata annak ellenőrzése, hogy az MIF-megállapodás cél általi korlátozásnak minősül-e.

A Főtanácsnoki indítvány 56-62. pontjai.

Az EUB C-382/12 P. sz. MasterCard és társai kontra Bizottság ügyben 2014. szeptember 11-én hozott itélete [EU:C:2014:2201]; a Törvényszék T-111/08 sz. MasterCard és társai kontra Bizottság ügyben 2012. május 24-én hozott ítélete [EU:T:2012:260]. Az ítéletek megerősítették a Bizottság határozatát a tekintetben, hogy a bankközi jutalék meghatározása a MasterCard mint vállalkozások társulásának döntése által, hatása szerint jogsértő volt.

$20 \quad$ A Fôtanácsnoki indítvány $63-73$ pontjai.

$21 \quad$ A Fốtanácsnoki indítvány $74-81$. pontjai. 


\subsubsection{A harmadik és a negyedik kérdés}

Az egymáshoz szorosan kapcsolódó harmadik és negyedik kérdéssel kapcsolatban a Főtanácsnoki indítvány a negyedik kérdést a harmadik kérdés előtt tárgyalja, így mi is ezt a sorrendet követjük. Megjegyezzük ugyanakkor, hogy a Bíróság ezt a két kérdést végül nem fogadta be, így ezeket csak a teljesség kedvéért mutatjuk be.

A negyedik kérdés arra vonatkozott, hogy a versenyhatóság köteles-e kifejezetten megjelölni azt, hogy a vállalkozás magatartása megállapodásnak vagy összehangolt magatartásnak minősül. A főtanácsnok szerint erre a kérdésre nemleges választ kell adni. Ennek indokaként hivatkozik az Anic Partecipazioni ügyben kifejtettekre és azt követő ítélkezési gyakorlatra, amely szerint a versenyhatóság nem köteles a magatartás meghatározott formáját megállapodásként vagy összehangolt magatartásként minősíteni. ${ }^{22}$ Hozzáteszi, hogy ezek a fogalmak bizonyos mértékben átfedik egymást, megnehezítve annak megállapítását, hogy egy megállapodás hol ér véget, és hol kezdődik az összehangolt magatartás. Ráadásul a jogsértések idővel is változhatnak. Ezért a Bíróság hangsúlyozta azt is, hogy az EUMSZ 101. cikk (1) bekezdése alapján lefolytatandó elemzés nem változik attól függően, hogy a magatartás megállapodás, összehangolt magatartás vagy vállalkozások társulása által hozott döntés. ${ }^{23}$

A Főtanácsnoki indítványban utolsóként kezelt harmadik kérdés arra kereste a választ, a kártyatársaságokat úgy kell-e kezelni, mint a MIF-megállapodás feleit, vagy, hogy összehangolt magatartásban vettek részt. Ezzel kapcsolatban az indítvány emlékeztet arra, hogy a negyedik kérdéssel kapcsolatban kifejtettek értelmében a versenyhatóság nem köteles a magatartás megállapodás vagy összehangolt magatartásként való minősítésére.

Ezt követően az indítvány azt elemzi, hogy van-e jelentősége annak, hogy a kártyatársaságok a megállapodás tárgyától eltérő piacon tevékenykednek. Ezt illetően rámutat arra, hogy az EUMSZ 101. cikk (1) bekezdése értelmében vett megállapodás fogalma nem korlátozódik az ugyanazon a piacon tevékenykedő vállalkozások közötti megállapodásokra. Erre számos példa található az Európai Unió Törvényszékének és Bíróságának ítélkezési gyakorlatában, illetve ezt megerősítette a Bíróság AC-Treuhand ítéletében is. ${ }^{24}$ Ráadásul véleménye szerint, az $A C$-Treuhand ügyhöz képest, jelen ügyben a kártyatársaságok nem pusztán elősegítői voltak a megállapodásnak, hiszen közvetlenebb és azonnali érdekük füződött a megállapodás sikeres teljesítéséhez, és az természetét tekintve közelebb áll egy vertikális megállapodáshoz. ${ }^{25}$

Ezzel kapcsolatban a Főtanácsnoki indítvány által tárgyalt utolsó kérdéskör arra vonatkozik, hogy a kártyatársaságok a teljes jogsértésért felelősnek tekinthetők-e azon bankok mellett, amelyek az MIF-megállapodás részesei voltak. A Főtanácsnoki indítvány szerint erre a kérdésre az ítélkezési gyakorlat választ ad olyan értelemben, hogy a jogsértésből adódó felelősség megállapíthatóságához azt kell bizonyítani, hogy az érintett

\footnotetext{
22 Az EUB C-49/92 P. sz. Bizottság kontra Anic Partecipazioni ügyben 1999. július 8-án hozott ítélet [EU:C:1999:356], 131-133. pontja.

23 A Főtanácsnoki indítvány 83-90. pontjai.

24 Az EUB C-194/14 P. sz. AC-Treuhand kontra Bizottság ügyben 2015. október 22-én hozott ítélete [EU:C:2015:717].

25 A Főtanácsnoki indítvány 91-103. pontjai.
}

Európai Tükör 2020/3. 
vállalkozás hozzá kívánt-e járulni a valamennyi résztvevő által követett közös célokhoz, és tudomása volt a más vállalkozások által ugyanezen célok elérése végett tervezett vagy ténylegesen megvalósított magatartásokról, illetve e magatartásokat észszerúen előre láthatta, és kész volt azok kockázatát elfogadni (Anic Partezipazioni). Ez alapján, mivel a kártyatársaságok ösztönözték a megállapodás létrejöttét, megkönnyítették elfogadását, elfogadták és alkalmazták azt, véleménye szerint megállapítható a kártyatársaságok részvétele. ${ }^{26}$

\subsection{A Budapest Bank itélet}

Az EUB ítélete következtetéseit tekintve az első két kérdés tekintetében lényegében követi a Főtanácsnoki indítványt, érvelésének logikai menete azonban helyenként eltér attól, míg a harmadik és negyedik kérdést nem vizsgálta, mivel azokat befogadhatatlannak ítélte. ${ }^{27}$

\subsubsection{Az első kérdés}

Az első kérdésre a Bíróság szerint azt a választ kell adni, hogy az EUMSZ 101. cikk (1) bekezdését akként kell értelmezni, hogy azzal nem ellentétes, ha ugyanazon versenyellenes magatartást e rendelkezés értelmében egyszerre versenykorlátozó célúnak és hatásúnak minősítik.

Elemzésének kiindulópontjaként az EUB rámutatott arra, hogy a Bíróságnak az LTM-ítélet ${ }^{28}$ óta érvényes állandó ítélkezési gyakorlata szerint az EUMSZ 101. cikk (1) bekezdésében szereplő „vagy” kötőszó miatt először is meg kell vizsgálni a megállapodás tulajdonképpeni célját. Amennyiben a versenyellenes cél bizonyított, már nem szükséges megvizsgálni annak versenyre gyakorolt hatásait, mert a vállalkozások közti egyeztetés bizonyos típusai elegendő károssági fokot mutatnak ahhoz, hogy arra a következtetésre lehessen jutni, hogy károsak a rendes verseny megfelelő működésére (ebben a tekintetben a Bíróság utal a MasterCard és Toshiba, CB és Maxima Latvija ítéletekre). ${ }^{29} \mathrm{~A}$ hatás általi vizsgálat csak abban az esetben szükséges, amennyiben az egyeztetés elemzése nem tár föl ilyen károssági fokot.

Másfelől az EUB aláhúzza, hogy a Bíróság egy és ugyanazon magatartás vonatkozásában már sokszor megállapította, hogy annak mind célja, mind pedig hatása a verseny korlátozása volt. Ebből pedig azt a következtetést vonja le, hogy az, hogy a cél szerinti versenykorlátozás megállapítása mentesíti a hatáskörrel rendelkező hatóságot

A Főtanácsnoki indítvány 104-108. pontjai.

Budapest Bank ítélet 87-91. pontjai.

Az EUB C-56/65. sz. Société Technique Minière kontra Maschinenbau Ulm ügyben hozott ítélete, [EU:C:1966:38].

29 Az EUB C382/12 P. sz. MasterCard és társai kontra Bizottság ügyben 2014. szeptember 11-én hozott ítélet [EU:C.2014:2201] 184. és 185. pontja; az EUB C373/14 P. sz. Toshiba Corporation kontra Bizottság ügyben 2016. január 20-án hozott ítélet [EU:C:2016:26] 26. pontja.

Európai Tükör 2020/3. 
e korlátozás hatásainak vizsgálata alól, semmiképpen nem jelenti azt, hogy a hatóság/ bíróság ne folytathatna le hatásvizsgálatot, amennyiben azt célszerúnek ítéli.

A Főtanácsnoki indítvánnyal azonosan rámutat arra, hogy a fentieket nem vonja kétségbe a megállapodás cél vagy hatás által korlátozóként való minősítése és a kiszabható bírságok közötti összefüggés, illetve az EUMSZ 101. cikk (3) bekezdés szerinti mentesülés alkalmazásának a lehetősége.

Végül hozzáteszi a Bíróság azt is, hogy mind cél és mind hatás általi versenykorlátozás minősítésének lehetősége nem mentesíti a hatóságokat azon kötelezettségük alól, hogy egyrészt az ezzel kapcsolatos megállapításokat a szükséges bizonyítékokkal alátámasszák, másrészt pedig pontosítsák, hogy az említett bizonyítékok mennyiben vonatkoznak az így megállapított korlátozás egyik vagy másik típusára. ${ }^{30}$

\subsubsection{A második kérdés}

A második kérdést a Bíróság lényegében nyitva hagyja, megállapítva, hogy az EUMSZ 101. cikk (1) bekezdését akként kell értelmezni, hogy a MIF-megállapodás nem minősíthető olyan megállapodásnak, amelynek az e rendelkezés értelmében vett „célja” a verseny megakadályozása, korlátozása vagy torzítása, hacsak e megállapodás a tartalmára, a célkitűzéseire és a hátterére tekintettel olyannak nem tekinthető, amely a verseny tekintetében elegendő károssági fokot mutat ahhoz, hogy ekként lehessen minősíteni, amit a kérdést előterjesztő bíróságnak kell megvizsgálnia.

Az e következtetésig vezető logikai lépéseken keresztül a Bíróság azonban felvázolja az elemzés elméleti kereteit.

Először is felidézi, hogy a Bíróság ítélkezési gyakorlata értelmében annak értékelése érdekében, hogy valamely vállalkozások közötti megállapodás vagy vállalkozások társulása által hozott döntés a verseny tekintetében elegendő károssági fokot mutat-e ahhoz, hogy az EUMSZ 101. cikk (1) bekezdése értelmében vett „cél általi” versenykorlátozásnak kelljen tekinteni, e megállapodás rendelkezéseinek tartalmát és az általa elérni kívánt célkitǔzéseket, valamint azt a gazdasági és jogi hátteret kell megvizsgálni, amelybe a megállapodás illeszkedik. Az említett háttér értékelése keretében figyelembe kell venni továbbá az érintett termékek vagy szolgáltatások jellegét, valamint az érintett piac vagy piacok múködésének és szerkezetének tényleges feltételeit is. ${ }^{31}$ Utal a hasonló módon kikristályozott joggyakorlatra, miszerint az, hogy egy intézkedés jogszerú célt (is) követ, önmagában nem zárja ki, hogy azt versenykorlátozó célúnak lehessen minősíteni, illetve hogy a felek szándéka ugyan nem feltétele a megállapodás korlátozó jellegének meghatározásához, de a versenyhatóságok figyelembe vehetik azt. ${ }^{32}$

Szintén a korábbi ítélkezési gyakorlattal egybehangzóan ismételten rögzíti, hogy a „cél általi” versenykorlátozás fogalmát „megszorítóan” kell értelmezni. A „cél általi” versenykorlátozás fogalma ugyanis a vállalkozások közötti egyeztetéseknek csak

A Budapest Bank ítélet 26-44. pontjai.

A Budapest Bank ítélet 51. pontjában hivatkozott EUB C67/13 P. sz. CB kontra Bizottság ügyben 2014. szeptember 11-én hozott ítélet [EU:C:2014:2204], 53. pontja, valamint az ott hivatkozott ítélkezési gyakorlat.

32 A Budapest Bank ítélet 52-53. pontjai. 
bizonyos típusaira alkalmazható, amelyek a verseny tekintetében elegendő károssági fokot mutatnak ahhoz, hogy úgy lehessen tekinteni, hogy hatásaikat nem szükséges megvizsgálni. Abban az esetben, ha az érintett megállapodást nem lehet versenykorlátozó célúnak minősíteni, meg kell vizsgálni, hogy e megállapodás tiltottnak tekinthető-e a versenyfeltételek azon változásai folytán, amelyek annak hatásaként következnek be. Ennek érdekében - mint azt a Bíróság több alkalommal megállapította - meg kell vizsgálni a verseny alakulását azon valós keretek között, amelyek mellett az akkor folyna, ha e megállapodás nem létezett volna, annak értékelése érdekében, hogy e megállapodás milyen hatással van a verseny olyan paramétereire, mint különösen a termékek vagy szolgáltatások ára, mennyisége és minősége. ${ }^{33}$

Rátérve a magyar ügy sajátosságaira, a Bíróság kiindulópontként emlékeztet arra, hogy a bankkártyarendszerek területén három különálló piacot lehet azonosítani: mindenekelőtt a „rendszerközi piacot”, amelyen a kártyarendszerek versenyeznek egymással, továbbá a „kibocsátói piacot”, amelyen a kibocsátó bankok versenyeznek a kártyabirtokosokból álló ügyfélkörért, végül pedig az „elfogadói piacot”, amelyen az elfogadó bankok versenyeznek a kereskedőkből álló ügyfélkörért. A MIF-megállapodás tekintetében a GVH a határozatában úgy ítélte meg, hogy a MIF-megállapodás különösen azért volt a céljánál fogva versenykorlátozó, mert először is semlegesítette a magyarországi rendszerközi piacon fennálló árverseny legfontosabb elemét; másodszor a bankok a magyarországi elfogadói piacon maguk is versenykorlátozó szerepet tulajdonítottak e megállapodásnak; harmadszor pedig a megállapodás ez utóbbi piacon szükségképpen kihatott a versenyre. A Bíróság hangsúlyozta, hogy kérdést előterjesztő bíróság feladata végleges értékelést lefolytatni azzal kapcsolatban, hogy e megállapodás versenykorlátozó célú volt-e, illetve hogy nem áll rendelkezésére az összes olyan elem, amely e tekintetben relevánsnak bizonyulhat. ${ }^{34}$

Ugyanakkor a Bíróság nem állt meg ezen a ponton, hanem az előterjesztett ügyben rendelkezésére álló információ birtokában a következő megfigyeléseket tette.

A MIF-megállapodás tartalma vonatkozásában megjegyezte, hogy nem vitatott, hogy e megállapodás egységesítette a bankközi jutalékokat, ugyanakkor megállapítva, hogy a MIF-megállapodáshoz hasonló megállapodás akár a két kártyás fizetési rendszer közötti verseny, akár pedig az elfogadó bankok között a kereskedői jutalék vonatkozásában fennálló verseny szempontjából nem rögzíti közvetlenül a beszerzési vagy eladási árakat, hanem csupán az elfogadó bankok költségének egyik vetületét egységesíti. Utalt ugyanakkor ezzel kapcsolatban arra, hogy az EUMSZ 101. cikk (1) bekezdése a) pontjának szövegéből kitűnően a közvetett árrögzítés is minősülhet célja szerint versenykorlátozónak.

Ennek ellenére, és azzal együtt, hogy a Bíróság elé terjesztett iratanyagból kitűnően a MIF-megállapodásban százalékos mértékeket és konkrét összegeket állapítottak meg a bankközi jutalékok rögzítése érdekében, e megállapodás tartalma a Bíróság szerint mégsem tár fel szükségképpen „cél általi” korlátozást, amennyiben az abban foglalt rendelkezések vonatkozásában nem bizonyított, hogy azok károsak a versenyre.

A Budapest Bank ítélet 54-55. pontjai.

A Budapest Bank ítélet 56-59. pontjai.

Európai Tükör 2020/3. 
Ennek a következtésnek a magyarázatát a Bíróság a korábbi Cartes Bancaires ügyben hozott ítéletre is hivatkozással abban látja, hogy annak értékelése érdekében, hogy valamely vállalkozások közötti egyeztetés jellegénél fogva káros-e a rendes verseny megfelelő működésére, figyelembe kell venni valamennyi, azon gazdasági vagy jogi háttérre vonatkozó releváns elemet, amelybe az említett összehangolás illeszkedik, különös tekintettel a szóban forgó szolgáltatások jellegére, valamint a piacok múködésének és szerkezetének tényleges feltételeire, anélkül, hogy jelentősége lenne annak, hogy az ilyen elem az érintett piac részét képezi-e, vagy sem. ${ }^{35}$

Figyelemre méltó, hogy a Bíróság a Cartes Bancaires ügyhöz hasonlóan itt is kiemelte, hogy a gazdasági és jogi háttér elemzésével kapcsolatban figyelembe kell venni különösen ha kétoldalú piacokról van szó, ahol a piac két oldala között kölcsönhatások vannak. ${ }^{36}$

A Bíróság utalt arra is, hogy nem zárható ki, hogy a rendelkezésre álló adatok alapján a MIF-megállapodás célja nem arra irányult, hogy a kereskedői jutalékok vonatkozásában küszöbértéket biztosítson, hanem arra, hogy az alapügyben vizsgált kártyás fizetési rendszerek mindegyikén belül bizonyos egyensúlyt teremtsen a „kibocsátási” tevékenységek és az „elfogadási” tevékenységek között, annak biztosítása érdekében, hogy a fizetési műveletek keretében történő kártyahasználat folytán keletkező bizonyos költségek fedezve legyenek, ezzel együtt védve e rendszereket azon nem kívánatos hatásoktól, amelyek a bankközi jutalékok, így pedig adott esetben a kereskedői jutalékok túl magas szintjéből származnának. ${ }^{37}$ A Bíróság szerint azt a felvetést is meg kell vizsgálni, hogy a bankközi jutalékok egységesítése versenyt indukálhatott-e, ami viszont a hatásvizsgálat körébe tartozó kérdés. ${ }^{38}$

A tapasztalat szerepével kapcsolatban kiemelte, hogy kellően szilárd, általános és megbízható tapasztalatnak kell fennállnia ahhoz, hogy megállapítható legyen, hogy egy megállapodás önmagában a jellegénél fogva káros a verseny megfelelő működésére. E tekintetben pedig meglátása szerint azon körülmények, amelyekre a GVH támaszkodott, vagyis lényegében a GVH határozathozatali gyakorlata, valamint az uniós igazságszolgáltatási fórumok ítélkezési gyakorlata a jelenlegi állás szerint éppen azt mutatja, hogy alapos vizsgálatot kell lefolytatni az ilyen megállapodás hatásaira vonatkozóan annak megállapítása érdekében, hogy e megállapodás ténylegesen versenykorlátozó volt-e. ${ }^{39}$

A MIF-megállapodás gazdasági-jogi környezetet illetően először is megjegyezte, hogy sem a kártyás fizetési rendszerek összetettsége, sem e rendszerek kétoldalú jellege mint olyan, sem pedig az érintett gazdasági szereplők különböző típusai közötti vertikális kapcsolatok fennállása nem képezheti önmagában akadályát a MIF-megállapodás „cél általi” korlátozásként minősítésének. Ezzel együtt azonban a versenyellenes célt változatlanul bizonyítani kell. ${ }^{40}$

35 Az EUB C67/13 P. sz. CB kontra Bizottság ügyben 2014. szeptember 11-én hozott ítélet [EU:C:2014:2204], 78. pontja.

A Budapest Bank ítélet 68. pontja.

A Budapest Bank ítélet 73. pontja.

A Budapest Bank ítélet 69-75. pontjai.

A Budapest Bank ítélet 76-79. pontjai.

A Budapest Bank ítélet 80-84. pontjai.

Európai Tükör 2020/3. 
Ezzel kapcsolatban a Bíróság aláhúzta, hogy amennyiben olyan körülmények állnak fenn, amelyek első ránézésre komolyan alátámaszthatják azt, hogy a MIF-megállapodás a bankközi jutalékok áremelkedése ellen ható ilyen nyomást gyakorolt, vagy legalábbis egymásnak ellentmondó vagy többértelmű utalások vannak e tekintetben, akkor nem állapítható meg, hogy e megállapodás a magyarországi elfogadói piacon „cél általi” versenykorlátozást valósított volna meg. Ebben az esetben alaposan meg kellene vizsgálni az említett megállapodás hatásait, hogy miként alakult volna a verseny, ha e megállapodás nem létezett volna. ${ }^{41}$

Végül kiemelte, hogy annak vizsgálata keretében, hogy a MIF-megállapodás „cél általi" korlátozásnak minősíthető-e, releváns az a körülmény is, hogy az e megállapodásban részt vevő felek a kibocsátó bankok ugyanúgy, mint az elfogadó bankok. Ez a Bíróság szerint arra utalhat, hogy e megállapodás révén nem csupán a kibocsátó bankok és az elfogadó bankok törekedhettek arra, hogy valamilyen módon összeegyeztethessék az adott esetben eltérő érdekeiket, hanem a kibocsátási és az elfogadási piacon egyaránt jelen lévő bankoknak az is szándékában állhatott, hogy a bankközi jutalék olyan mértékét érjék el, amely lehetővé teszi az e két piacon gyakorolt tevékenységeik lehető legjobb védelmét (vagyis a kártyás fizetési rendszeren belüli egyensúly biztosítását). ${ }^{42}$

\subsubsection{A harmadik és negyedik kérdés}

A harmadik és a negyedik kérdést hipotetikus jellegük folytán a Bíróság elfogadhatatlannak tekintette, mivel, mint azt a kérdést előterjesztő bíróság is kifejezetten elismerte, az uniós jognak e bíróság harmadik és negyedik kérdésével kért értelmezése nem ahhoz szükséges, hogy e bíróság az előtte jelenleg folyamatban lévő jogvitát elbírálhassa, hanem egy esetleges jövőbeli nemzeti eljárás keretében bizonyulhat hasznosnak. ${ }^{43}$

Az elfogadhatóság kapcsán a szerző megjegyzi, hogy az állandó ítélkezési gyakorlat szerint a Bíróság és a nemzeti bíróságok között az EUMSZ 234. cikk szerinti együttmüködés értelmében egyedül az alapeljárást folytató és a meghozandó bírósági döntésért felelős nemzeti bíróság jogosult mérlegelni - az ügy sajátosságaira figyelemmel - egyrészt azt, hogy az előzetes döntéshozatal szükséges-e a döntéshozatalhoz, másrészt azt, hogy a Bíróság számára feltett kérdések relevánsak-e. Így tehát amennyiben az előzetes döntéshozatalra előterjesztett kérdések a közösségi jog értelmezésével kapcsolatosak, a Bíróság fő szabály szerint köteles eljárni. Mindazonáltal, mint ahogyan azt a Bíróság korábbi esetjogában kifejtette, kivételes esetekben - saját hatáskörének vizsgálata céljából - jogosult megvizsgálni azokat a körülményeket, amelyek között a nemzeti bíróság hozzá fordult. Azonban a nemzeti bíróság előzetes döntéshozatalra előterjesztett kérdéséről való határozathozatal megtagadásának csak akkor van helye, ha nyilvánvaló, hogy a kérdéses közösségi jogszabály értelmezése, amelyet a nemzeti bíróság kért nem függ össze az alapeljárás tényeivel vagy céljával, vagy ha a probléma elméleti jellegű, illetőleg

A Budapest Bank ítélet 81-83. pontjai.

A Budapest Bank ítélet 84-85. pontjai.

A Budapest Bank ítélet 87-91. pontjai.

Európai Tükör 2020/3. 
ha a Bíróság nem rendelkezik azon ténybeli, illetve jogi adatokkal, amelyek a feltett kérdések hasznos megválaszolásához szükségesek. ${ }^{44}$

\subsection{A bankközi jutalék az európai versenyjogi gyakorlatban}

Az ítéletnek a megfelelő kontextusba illesztése érdekében rövid kitérőként bemutatjuk az Európai Bizottság gyakorlatát a többoldalú bankközi jutalékokkal kapcsolatban.

A Bizottság mintegy két évtizede folyamatosan foglalkozik a bankközi jutalékokkal, és az antitrösztügyekben hozott döntések, illetve azok tapasztalatai uniós szabályozást is indukáltak.

A 2000-es évek elején a Bizottság a Visa II. ügyben már megállapította, hogy a bankközi jutalék olyan versenytársak közötti megállapodásnak minősül, amely korlátozza a bankokat árazási politikájukban, és hatását tekintve torzítja a versenyt a Visa kártyák kibocsátói és elfogadói piacán egyaránt. Ekkor még a Bizottság - ötéves időtartamra - egyedi mentesítésben részesítette a magatartást. ${ }^{45}$

Ezt követően, 2007-ben a Bizottság a MasterCard I. ügyben szintén arra a megállapításra jutott, hogy a bankközi jutalék hatásában korlátozza a versenyt az elfogadói piacon, ugyanis küszöbárként árnövelő hatása van a kereskedői díj tekintetében. A versenykorlátozó cél tekintetében azonban a Bizottság már nem foglalt egyértelműen állást arra tekintettel, hogy a versenykorlátozó hatás esetén a célzat bizonyítása nem szükséges a jogsértés megállapításához. Azonban azt rögzítette, hogy az MIF árrögzítő természete miatt versenykorlátozó célzatú is lehet, függetlenül attól, hogy mi volt a felek szubjektív szándéka. A MasterCard jogorvoslattal élt a Bizottság döntésével szemben, amelyet azonban mind a Törvényszék, mind az Európai Unió Bírósága jóváhagyott. ${ }^{46}$

A MasterCard I. ügy lezárását követően a Visa ellen is új ügy indult, amely kötelezettségvállalással zárult. ${ }^{47}$ Ebben az ügyben a Bizottság előzetes álláspontjában már cél és hatás szerinti versenykorlátozásnak minősítette a multilaterális bankközi jutalékokat.

2015-ben a fenti eljárások tapasztalatai alapján európai szintű szabályozást fogadtak el - a regionális bankközi jutalékokat mindkét kártyatársaság esetében a betéti kártyás tranzakciók esetén 20 bázispontos, míg a hitelkártyás tranzakciók kapcsán 30 bázispontos értékben maximalizálták. ${ }^{48}$ Időközben számos uniós versenyhatóság is eljárásokat indított a bankközi jutalékok kapcsán, amely annak veszélyét hordozta magában, hogy tagállamonként eltérő megközelítés érvényesül a bankközi jutalékok versenyjogi értékelése kapcsán.

$44 \quad$ Ebben a tekintetben lásd a Budapest Bank ítélet 29. pontjában hivatkozott 2006. július 13-i Manfredi és társai ítéletet, C295/04-C298/04, EU:C:2006:461, 27. pontját, valamint az ott hivatkozott ítélkezési gyakorlatot.

$45 \mathrm{COMP} / 29.373$ - Visa International.

46 T-111/08 és C-382/12 P. sz. MasterCard és társai kontra Bizottság ügyek. A Törvényszék a MasterCard jogorvoslati kérelmét elutasította, amely ítéletet az Európai Bíróság megerősített.

47 COMP/39.398 - Visa MIF.

48 A kártyaalapú fizetési múveletek bankközi jutalékairól szóló 2015. április 29-i (EU) 2015/751 európai parlamenti és tanácsi rendelet. 
Ezzel azonban a bankközi jutalékkal kapcsolatos antitrösztügyek még nem értek véget - 2019 januárjában született döntés a MasterCard II. ügyben, amely az EGT-n kívül kibocsátott kártyákkal végrehajtott fizetések kapcsán alkalmazott bankközi jutalékokat, és a kártyatársaság határokon átnyúló bankkártya-elfogadással kapcsolatos korlátozásait marasztalta el. ${ }^{49}$

Végül, szintén 2019-ben a Bizottságnak a Visával szemben, szintén az EGT-n kívül kibocsátott kártyákkal végrehajtott fizetések kapcsán alkalmazott bankközi jutalékokkal kapcsolatos eljárása ismét a Visa kötelezettségvállalásával zárult. ${ }^{50}$

\subsection{Az itélet jelentösége}

Az ítélet több szempontból jelentős és továbbfejleszti az európai versenyjogot. Egyrészt tisztázza a cél és hatás szerinti versenykorlátozás együttes megállapíthatóságának követelményeit. Másrészt továbbviszi és továbbfejleszti a Bíróságnak a cél szerinti korlátozás megállapításával kapcsolatos ítélkezési gyakorlatát. A Budapest Bank ítélet jelentősége a többoldalú piacokkal kapcsolatos megállapításai miatt a jövőben akár a digitális szektorral kapcsolatos ügyekben is releváns lehet.

A szerző véleménye szerint az ítélet leginkább figyelemre méltó jellegzetessége, hogy a Bíróság az eddigieknél magasabbra teszi a cél szerinti versenykorlátozás megállapíthatóságának mércéjét. Kiemelendő, hogy ezt annak ellenére, illetve azzal együtt teszi, hogy ebben az ügyben - a korábbi Cartes Bancaires üggyel ellentétben - két versenytárs kártyarendszer közötti horizontális árrögzítő megállapodást is érint, nem pedig egy, csak az adott kártyarendszer müködésével kapcsolatos, rendszeren belüli díjak rögzítését.

A cél szerinti versenykorlátozás megállapíthatóságának szűkítő értelmezése a magas szintű korábbi tapasztalat megkövetelésén, a „counterfactual” értékelés jogi tesztbe való beemelésén, illetve a korlátozás esetleges egyéb legitim céljai megvizsgálására vonatkozó követelmény hangsúlyozásán keresztül valósul meg.

A következőkben az ítéletnek, a szerző nézete szerint legjelentősebb megállapításait és következtetéseit mutatja be és értékeli.

\subsubsection{A cél és hatás szerinti jogsértés bizonyítási mércéje}

A Bíróság következtetése szerint nincs akadálya a cél és hatás szerinti versenykorlátozás egyidejű megállapíthatóságának. Ugyanakkor a Bíróság - a Főtanácsnoki indítvánnyal

COMP/40.049 számú eljárás.

Antitrust: Commission accepts commitments by Mastercard and Visa to cut inter-regional interchange fees.

European Commission, 2019.

Európai Tükör 2020/3. 
egyezően - kiemelte azt is, hogy ebben az esetben az eljáró hatóságnak/bíróságnak mindkét megállapítását bizonyítania kell. ${ }^{51}$

A szerző szerint ugyanakkor ez a következtetés nem teljesen konzisztens a cél/ hatás szerinti jogsértés bizonyításával kapcsolatos esetjoggal. Hiszen, mint azt a Bíróság ebben az ügyben is kiemelte, amennyiben a versenyellenes cél bizonyított, már nem szükséges megvizsgálni annak versenyre gyakorolt hatásait, mert a vállalkozások közti egyeztetés bizonyos típusai elegendő károssági fokot mutatnak ahhoz, hogy arra a következtetésre lehessen jutni, hogy károsak a rendes verseny megfelelő múködésére. ${ }^{52}$ Ha pedig az adott korlátozás cél szerinti versenykorlátozásnak minősül, és így elegendő károssági fokot mutat, akkor, pusztán logikai alapon, kérdésként merülhet fel, hogy miért kellene mégis a versenyhatóságnak a cél szerinti versenykorlátozás megállapítása mellett, a hatás szerinti jogsértés megállapításához egy teljes hatásvizsgálatot is lefolytatnia annak teljes bizonyítási terhe mellett.

Továbbá a szerző szerint a kettős minősítésnek valószínűleg új típusú jogsértések esetén lehet csak gyakorlati jelentősége, amikor a cél szerinti jogsértés megállapíthatósága kérdéses, és ezért az eljáró hatóság esetlegesen mindkét alapon bizonyítani kívánja a jogsértést. Kérdéses azonban, hogy ebben az esetben már önmagában az a tény, hogy a hatóság értékelése szerint is hatásvizsgálat lefolytatása szükséges, nem vonná-e kétségbe a cél szerinti versenykorlátozás megállapíthatóságát. Következésképpen a cél és hatás szerinti jogsértés együttes megállapítása feltehetőleg leginkább elméleti lehetőség marad majd.

Ebben az összefüggésben a szerző megjegyzi, hogy bírságközleménye értelmében a magyar versenyhatóság figyelembe veszi a piaci hatást a jogsértés súlyának és így a bírságnak a meghatározásakor. Ez a „piaci hatás” azonban nem feleltethető meg a Budapest Bank ítélet tárgyát képező, a jogsértés megállapításához szükséges hatásvizsgálattal, az előbbi csupán a jogsértés súlyára utaló korlátozott számú körülmény (például piaci részesedések, jogsértés megvalósulása) vizsgálatát jelenti. ${ }^{53}$

Ezért, mivel a vonatkozó jogszabályok és joggyakorlat értelmében a bírság kiszabásánál a hatás vizsgálata nem követelmény, valószínútlennek tűnik, hogy pusztán a bírság meghatározása érdekében a versenyhatóságok teljes hatásvizsgálatot végezzenek.

51 A Budapest Bank ítélet 43. pontja szerint: „[A] hatáskörrel rendelkező hatóságot vagy bíróságot megillető azon lehetőség, hogy ugyanazon versenyellenes magatartást mind »cél általi«, mind pedig »hatás általi« korlátozásnak minősítse, e hatóságot vagy bíróságot semmilyen módon nem mentesíti azon kötelezettség alól, hogy egyrészt az ezzel kapcsolatos megállapításait a szükséges bizonyítékokkal alátámassza, másrészt pedig pontosítsa, hogy az említett bizonyítékok mennyiben vonatkoznak az így megállapított korlátozás egyik vagy másik típusára.”

52 A Budapest Bank ítélet 36. pontja értelmében: „Így általánosan elfogadott, hogy az összejátszásra irányuló bizonyos magatartások, úgymint a kartellek révén való horizontális árrögzítéshez vezető magatartások úgy tekinthetők, hogy annyira valószínűen negatív hatásokkal járnak különösen a termékek és szolgáltatások árára, mennyiségére vagy minőségére, hogy úgy tekinthető, hogy az EUMSZ 101. cikk (1) bekezdésének alkalmazásában szükségtelen bizonyítani, hogy tényleges hatásokat gyakorolnak a piacra. A tapasztalat ugyanis azt mutatja, hogy az ilyen magatartások a termelés csökkenésével és az árak növekedésével járnak, és a forrásoknak különösen a fogyasztók hátrányára való kedvezőtlen elosztásához vezetnek (2014. szeptember 11i CB kontra Bizottság ítélet, C67/13 P, EU:C:2014:2204, 51. pont; 2015. november 26i Maxima Latvija ítélet, C345/14, EU:C:2015:784, 19. pont)" (szerző által kiemelt).

53 Lásd a Gazdasági Versenyhivatal Elnökének és a Gazdasági Versenyhivatal Versenytanácsa Elnökének 11/2017. közleménye 26-27. pontjait. 
Végül ebben a tekintetben érdemes utalni a Főtanácsnoki indítványra is, amely kifejtette, hogy „nincs automatikus összefüggés a megállapodás cél vagy hatás által korlátozóként való minősítése és a felelős vállalkozással szemben kiszabható bírságok meghatározása között. Az 1/2003/EK rendelet 23. cikke (3) bekezdésének megfelelően »[a] bírság mértékének meghatározásakor tekintetbe kell venni mind a jogsértés súlyát, mind annak időtartamát«. ${ }^{54}$ Kétségtelen, hogy azokat a megállapodásokat, amelyeket a versenyt cél által korlátozónak minősítik, nagyobb valószínűséggel tekinthetik úgy, hogy azok a versenyjog súlyos megsértéséhez vezetnek. Mindazonáltal ez pusztán annak a ténynek az elkerülhetetlen következménye, hogy a "cél általi korlátozások « fogalma csak az olyan típusú egyeztetésekre alkalmazható, amelyek »a verseny tekintetében elegendő károssági fokot mutatnak«. Ennél is fontosabb, hogy egyáltalán nem zárható ki, hogy egyrészt bizonyos cél általi korlátozások valamennyi releváns körülmény tükrében kevésbé súlyos jogsértéseknek tekinthetők, másrészt hogy a hatás általi korlátozások a versenyjog terén a különösen súlyos jogsértésekkel lehetnek egyenértékűek." ${ }^{55}$

\subsubsection{A cél szerinti jogsértés megállapításának sztenderdje}

A versenyjogi körökben az Allianz Hungária ügy óta élénk eszmecsere folyik a cél alapú jogsértés bizonyítási sztenderdjéről, az alkalmazandó jogi teszt egyes elemeiről. ${ }^{56} \mathrm{~A}$ Cartes Bancaires ügyben a Bíróság megállapította, hogy a cél szerinti jogsértés kivételesen állapítható meg, és a jogi és gazdasági környezet vizsgálata megkérdőjelezheti a cél szerinti jogsértést. ${ }^{57}$

A Budapest Bank ítélet ugyanakkor további nagy lépést tett a cél szerinti jogsértés fogalmának és különösen az új típusú jogsértések cél szerinti jogsértésként való minősíthetősége további szűkítése irányában.

A szerző véleménye szerint a Bíróságnak az Allianz Hungária üggyel kezdődő, a cél szerinti jogsértés határainak kijelölésére tett kísérlete a Budapest Bank ítélettel olyan fázisba ért, hogy értelmezése már felveti az EUMSZ 101. (1) cikkével való konzisztencia kérdését is. Az ítélet ugyanis a hatás elemzését is beemeli a cél szerinti vizsgálat körébe a lenti 3.4.4.2. pontban említett counterfactual típusú vizsgálat előírásával. Ezáltal pedig felmerülhet, hogy összhangban van-e ez a megközelítés az EUMSZ 101. (1)

54 Az [EUMSZ 101. cikkben] és [az EUMSZ 102. cikkben] meghatározott versenyszabályok végrehajtásáról szóló, 2002. december 16-i tanácsi rendelet (HL 2003. L 1., 1.; magyar nyelvű különkiadás 8. fejezet, 2. kötet, 205.).

55 Lásd a Fő́tanácsnoki indítvány 33. pontját.

56 Lásd pl.: Nagy, István Csongor: The New Concept of Anti-Competitive Object: A Loose Cannon in EU Competition Law. European Competition Law Review, 36. (2015), 4. 154-159.; illetve Nagy, István Csongor: Anticompetitive Object/Effect: An Overview of EU and National Case Law. e-Competitions Bulletin Anticompetitive object/effect, Art. N 91905 (2019); illetve a jelen ügyet illetően Nagy, István Csongor: Are Payment Card Systems' Multilateral Interchange Fees Anticompetitive by Object under EU Competition Law? Competitition Policy International, 2020; illetve Marian Ioannidou - Julian Nowag: Can two wrongs make a right? Reconsidering minimum resale price maintenance in the light of Allianz Hungária. European Competition Journal, 11. (2015), 2-3. 340-366.

57 Az EUB C67/13 P. sz. CB kontra Bizottság ügyben 2014. szeptember 11-én hozott ítélet [EU:C:2014:2204], lásd különösen annak 77-78. pontjait. 
cikkével és a Bíróság ítélkezési gyakorlatával is, amely szerint minden olyan megállapodás tilos, amelynek célja vagy hatása a verseny korlátozása, és amennyiben a cél szerinti versenykorlátozást megállapították, már nincs szükség a hatások vizsgálatára.

\subsubsection{Az árrögzítés nem feltétlenül cél szerint versenykorlátozó}

Először is figyelemre méltó ebben a tekintetben, hogy a Bíróság egy horizontális árrögzítő megállapodás tekintetében állapította meg, hogy az nem feltétlenül korlátozza célja szerint a versenyt - annak ellenére, hogy a horizontális ármegállapodások tekintetében a korábbi esetjog töretlen volt e tekintetben. ${ }^{58}$

Ezenkívül a Bíróság elemzésében figyelmen kívül hagyta azt a bírósági gyakorlatban kidolgozott tételt is, amely szerint minden gazdasági szereplőnek önállóan kell meghatároznia a piacon követni kívánt politikáját, és a verseny bizonytalanságát gyakorlati együttműködéssel helyettesítő megállapodások cél szerinti jogsértésnek minősülhetnek. ${ }^{59}$

Ebben az összefüggésben a Bíróság kiemelte, hogy a MIF-megállapodás célkitúzése lehetett az egyes kártyarendszereken belül, a kibocsátási és elfogadási tevékenységek közötti egyensúly biztosítása - ugyanakkor a szerző szerint a Bíróság nem magyarázza meg, hogy mennyiben releváns ez a szempont a kártyarendszerek közötti megállapodás versenykorlátozó jellegének értékelésében. ${ }^{60}$

\subsubsection{A tapasztalat szerepe}

A tapasztalat szerepét illetően a Bíróság szintén új, többletkövetelményt fogalmaz meg a korábbi esetjoghoz képest. A Budapest Bank ítélet szerint ugyanis kellően szilárd, általános és megbízható tapasztalatnak kell fennállnia ahhoz, hogy megállapítható legyen, hogy egy megállapodás önmagában a jellegénél fogva káros a verseny megfelelő múködésére, és ebben a tekintetben utal a Főtanácsnoki indítványban foglaltakra. ${ }^{61} \mathrm{~A}$ hivatkozott Főtanácsnoki indítvány megkérdőjelezte, hogy az Európai Unió Törvényszékének

$58 \quad$ Arra egyébként a Bíróság maga is utal a Budapest Bank ítélet 62. pontjában, hogy a közvetett árrögzítés is lehet cél szerinti versenykorlátozó: „[A]z EUMSZ 101. cikk (1) bekezdése a) pontjának magából a szövegéből kitűnik, hogy »a beszerzési vagy eladási árak [...] közvetett rögzítés[éről]« szóló megállapodás is minősülhet olyannak, amelynek célja a belső piacon belüli verseny megakadályozása, korlátozása vagy torzítása. Felmerül tehát a kérdés, hogy a MIFmegállapodáshoz hasonló megállapodás olyannak tekinthetőe, amely az e rendelkezés értelmében vett közvetett árrögzítés körébe tartozik, amennyiben közvetetten meghatározta a kereskedői jutalékokat."

Lásd az EUB C209/07 sz. Beef Industry Development Society and Barry Brothers ügyben 2008. november 20-án hozott ítélet [EU:C:2008:643] 34. pontját, illetve az EUB C307/18 sz. Generics ügyben 2020. január 30-án hozott ítélet [ECLI:EU:C:2020:52] 83. pontját.

60 A Budapest Bank ítélet 73. pontja. Míg ez a megfontolás releváns volt a Cartes Bancaires ügyben, ahol a kártyarendszeren belüli díjak meghatározásáról volt szó, jelen esetben nem világos, hogy miért lett volna szükség a két kártyatársaság közötti megállapodáshoz a rendszereken belüli egyensúly eléréséhez. Lásd a Budapest Bank ítélet 76-79. pontjait. 
és Bíróságának a MasterCard ügyben hozott ítéletei ${ }^{62}$ és a Bizottság gyakorlata kellően egyértelmű és egységes ebben a tekintetben, illetve kétséges, hogy néhány közigazgatási határozat, amely az egyeztetés hasonló formáira vonatkozik kellő tapasztalatnak minősülhet. Rámutatott továbbá arra, hogy más nemzeti hatóságok gyakorlata, illetve független szerzők által készített nemzetközi közgazdasági elveken, módszereken alapuló tanulmányokban kimutatható kellő mértékű egyetértés is hasznos lenne a szükséges tapasztalat igazolására. ${ }^{63}$

A szerző szerint ez a megközelítés majdnem teljes előzetes konszenzust kívánna meg a jogsértés jellegét illetően a hatósági gyakorlatban és a szakirodalomban. Ennek a mércének való megfelelés azonban az új típusú jogsértések esetén a szerző szerint nem életszerû, és így a gyakorlatban majdnem minden új típusú jogsértés esetén hatás által vizsgálatra kényszerítené a jogalkalmazókat.

Mindenesetre elgondolkodtató, hogy az EUB-nak a Budapest Bank ügyben hozott ítéletét megelőzően sem a 2018-ban hozott Hoffman-La Roche ügyben előzetes döntéshozatali eljárásban hozott ítéletében, ${ }^{64}$ sem pedig a szintén előzetes döntéshozatali eljárás kapcsán 2020 januárjában hozott Generics UK ítéletében ${ }^{65}$ nem említette a tapasztalatnak az elemzésben játszott szerepét, annak ellenére, hogy mindkét ügyben újszerű jogsértésekről volt szó. ${ }^{66} \mathrm{Az}$ értelmezést talán tovább árnyalja majd az EUB a Lundbeck ügyben hozandó ítéletében, ahol viszont kifejezetten felmerült ez a kérdés. ${ }^{67}$

\subsubsection{Gazdasági-jogi kontextus / kétoldalú piacok}

A Bíróság a Cartes Bancaires ügyhöz hasonlóan kiemelte, hogy a gazdasági és jogi háttér elemzésével kapcsolatban figyelembe kell venni, hogy kétoldalú piacokról van szó, és így

62 Az EUB C-382/12 P. sz. MasterCard és társai kontra Bizottság ügyben 2014. szeptember 11-én hozott ítélete [EU:C:2014:2201]; a Törvényszék T-111/08 sz. MasterCard és társai kontra Bizottság ügyben 2012. május 24-én hozott ítélete [EU:T:2012:260]. Az ítéletek megerősítették a Bizottság határozatát a tekintetben, hogy a bankközi jutalék meghatározása a MasterCard mint vállalkozások társulásának döntése által, hatása szerint jogsértő volt.

63 A Főtanácsnoki indítvány 63-73. pontjai.

64 Az EUB C179/16. sz. F. Hoffmann-La Roche és társai ügyben 2018. január 23-án hozott ítélete [ECLI:EU:C:2018:25].

65 Az EUB C307/18 sz. Generics ügyben 2020. január 30-án hozott ítélete [ECLI:EU:C:2020:52].

66 Ez a megállapítás akkor is helytálló, ha a Bíróság ítélkezési gyakorlata már utalt a múltbeli tapasztalat kérdésére. Például az EUB C286/13 P. sz. Dole Food et Dole Fresh Fruit Europe/Bizottság ügyben 2015. március 15-én hozott ítélet [EU:C:2015:184] 115. pontja ugyanis már kimondta, hogy: „Így általánosan elfogadott, hogy bizonyos összejátszásra irányuló magatartások, úgymint a kartellek révén való horizontális árrögzítéshez vezető magatartások úgy tekinthetők, hogy annyira valószínűen negatív hatásokkal járnak különösen az áruk és szolgáltatások árára, mennyiségére vagy minőségére, hogy úgy tekinthető, hogy az EK 81. cikk (1) bekezdésének alkalmazásában szükségtelen bizonyítani a piacra gyakorolt tényleges hatásaikat. A tapasztalat ugyanis azt mutatja, hogy az ilyen magatartások a termelés csökkenésével és az árak növekedésével járnak, és a forrásoknak különösen a fogyasztók hátrányára való kedvezőtlen elosztását eredményezik." (szerző által kiemelt).

67 A tapasztalat szerepét illetően lásd különösen a Törvényszék T472/13 sz. Lundbeck ügyben hozott ítélete [EU:T:2016:449], 432-438. pontjait. Az ítélet ellen fellebbezést nyújtottak be - a tapasztalat szerepével kapcsolatban Kokott fötanácsos a Törvényszékkel egyetértve foglalt állást véleményében [ECLI:EU:C:2020:428], lásd különösen a 155-157. pontokat.

Európai Tükör 2020/3. 
a két oldal között kölcsönhatás van, és az MIF-megállapodás a két oldal közötti egyensúly megteremtését célozhatta. ${ }^{68}$

Egyes elemzők értékelése szerint a Budapest Bank ítéletnek az erre vonatkozó megállapításaiból akár olyan következtetés is levonható, hogy a Bíróság érvelése akár a más platformok által alkalmazott korlátozások gazdasági racionalitásával kapcsolatban is alkalmazható lenne, hiszen általában azok célja is a különböző felhasználói csoportok közötti egyensúly megteremtése. Ez pedig azt jelentené, hogy a platformok által alkalmazott versenykorlátozó kikötésekkel kapcsolatban, figyelembe véve a tapasztalat korlátozott voltát is, majdnem mindig teljes hatásvizsgálatot kellene lefolytatni. ${ }^{69}$

A szerző véleménye szerint egy ilyen értelmezés sem zárható ki, hiszen, különösen a tapasztalat szerepével kapcsolatosan kifejtettek miatt, az ítélet kapaszkodót kínál tágabb értelmezésre. Azonban ezzel együtt azt sem lehet figyelmen kívül hagyni, hogy a Bíróság Budapest Bank ügyben hozott ítélete az adott ügy specifikus tényein alapul, és semmi jel nem utal arra, hogy a Bíróság a platformokkal kapcsolatos jövőbeni jogvitákkal kapcsolatban kívánt volna útmutatást adni.

Ebben a tekintetben figyelemre méltó a Budapest Bank ítélet 69. pontja is, amely szerint csak a ténylegesen bizonyított célkitúzések vehetők figyelembe, ami arra utal, hogy ebben a tekintetben a Bíróság a kimentési lehetőséget szúken kívánta értelmezni, arra az esetre korlátozva, ha az esetleges legitim célkitűzések léte ténylegesen bizonyítást nyer. ${ }^{70}$

\subsubsection{Gazdasági-jogi kontextus / a verseny hipotetikus körülményeinek elemzése a megállapodás hiányában (az úgynevezett „counterfactual”)}

A verseny körülményeinek a feltételezetten jogsértő megállapodás hiányában történő hipotetikus elemzése (úgynevezett „counterfactual” elemzés) a versenyjogi vizsgálat során annak figyelembevételét jelenti, hogy miként alakulhatott volna a verseny a feltételezetten versenykorlátozó kikötés/magatartás hiányában.

Ezt a típusú elemzést eddig csak a feltételezett jogsértés hatásainak megállapításához követelte meg a bírói gyakorlat. ${ }^{11}$ Azt, hogy a hatások ilyen vizsgálata nem szükséges

A Budapest Bank ítélet 68-73. pontjai.

Daniel Mandrescu: Restrictions of competition by object and multi-sided platforms - insights from Budapest Bank. 2020.

70 Ebben az öszefüggésben érdemes rámutatni, hogy a Bíróság a Budapest Bank ítélet 52. pontjában már rögzítette, hogy önmagában az, hogy valemely magatartás jogszerû célt követ, másik jogellenes célkitűzés fennállása mellett nem zárja ki azt, hogy a szóban forgó magatartást versenykorlátozó célúnak lehessen minősíteni.

71 Az alapelvet az EUB C-56/65. sz. Société Technique Minière kontra Maschinenbau Ulm ügyben hozott ítélete [EU:C:1966:38] 8. pontjában rögzítették, amelyet azóta számos ügyben megerősítettek az európai bíróságok. 
a cél általi versenykorlátozás megállapításához, a Törvényszék 2018-as Lundbeck ítéletében kifejezetten rögzítette is. ${ }^{72}$

A Bíróság azonban a jelen cikk tárgyát képező ítéletében kifejezetten előírja azt is, hogy egy counterfactual típusú elemzés a gazdasági-jogi kontextus vizsgálatának körében megkérdőjelezheti a cél szerinti versenykorlátozás minősítést is, amennyiben olyan körülmények állnak fenn, amelyek a priori komolyan alátámaszthatják azt, hogy a feltételezetten jogsértő magatartás hiányában a verseny korlátozottabb lett volna, vagy legalábbis egymásnak ellentmondó vagy többértelmü utalások vannak e tekintetben. ${ }^{73}$

Ezzel ugyan expressis verbis az EUB nem teszi az eljáró versenyhatóságok kötelezettségévé, hogy erre vonatkozóan kifejezett counterfactual vizsgálatot folytassanak le, ugyanakkor egyértelmúvé teszi, hogy amennyiben a bizonyítékok alapján első ránézésre ilyen körülményeket lehet azonosítani, akkor hatás szerinti vizsgálatnak lehet helye. Ezzel az EUB gyakorlatilag mégis beemeli ezt az eddig csak a hatásvizsgálat keretében alkalmazandó elemzést a cél szerinti jogsértés tesztjébe, hiszen a cél szerinti jogsértés ezentúl nem lesz megállapítható, ha bármilyen olyan körülmény merül fel, amely kérdésessé teheti a feltételezett jogsértés versenyre gyakorolt hatását. Ráadásul az EUB általi bizonyítási sztenderd („legalábbis egymásnak ellentmondó vagy többértelmú utalások”) annyira alacsony, hogy az alapján feltehetőleg sok esetben szükséges lesz ilyen vizsgálatra az eljárás alá vontak előterjesztései alapján. ${ }^{74}$

\subsubsection{Az ítélet lehetséges gyakorlati következményei}

A versenyjogi jogérvényesítés európai és tagállami szinten is több kihívással néz szembe. Részben a gazdaság szerkezetének átalakulása, a digitális/online iparágak gyors erősödése miatt, politikailag egyre nagyobb az elvárás a versenyhatóságok felé eljárásaik minél gyorsabb lefolytatására, a problémásnak vélt területeken való minél gyorsabb beavatkozás érdekében.

Ugyanakkor az EUB esetjoga, amelybe a Budapest Bank ítélet is illeszkedik, nem kínál olyan kapaszkodót, amelynek segítségét a versenyhatóságok felhasználhatnák az eljárások gyorsítása érdekében. Éppen ellenkezőleg, a cél szerinti jogsértés megállapíthatóságának egyre szigorodó feltételei a hatáselemzés irányába terelnék

72 Lásd a T472/13. sz. Lundbeck kontra Bizottság ügyben 2016. szeptember 8-án hozott ítélet [EU:T:2016:449] 473. pontját: „Amellett, hogy nehezen lenne kivitelezhető, mivel azt követelné meg a Bizottságtól, hogy rekonstruálja azokat az eseményeket, amelyek a vitatott megállapodások hiányában történtek volna, holott azok célja éppen a generikus vállalkozások piacra lépésének késleltetése volt (lásd a fenti 138. és 139. pontot), a hipotetikus alternatív forgatókönyv vizsgálata inkább a vitatott megállapodások által a piacra gyakorolt hatások vizsgálatához hasonlít, mint azok versenyre gyakorolt kellően káros hatásának objektív vizsgálatához. Márpedig a hatások ilyen vizsgálata nem szükséges a cél általi versenykorlátozás fennállására alapított elemzés keretében [...]."

73 Lásd a Budapest Bank ítélet 81-83. pontjait.

74 Ebben a tekintetben figyelemre méltó, hogy a Budapest Bank ítélet nem vette át a Főtanácsnoki indítvány által használt „első látásra ésszerűen kétségbe vonja az általános konvencionális ismeretet” megfogalmazást, hanem annál még alacsonyabbnak tủnik. 
a jogalkalmazókat. Ez azonban egy sokkal erőforrás- és időigényesebb feladat, amelynek alkalmazása az eljárásokat lelassítja, és így a piaci beavatkozás időszerűségét kevéssé képes szolgálni.

A szerző véleménye szerint ez feltehetőleg hozzájárul ahhoz, hogy az európai versenyhatóságok alternatív eszközöket is keresnek a versenyproblémák kezelésére. Jól tetten érhető ez a trend az Európai Bizottság esetében is, amely már bejelentette az ideiglenes intézkedések aktívabb használatát, ${ }^{75}$ egy új ex-ante versenyfelügyeleti eszköz bevezetését, illetve digitális platformokra szabályozás alkotását, amelyekkel a hagyományos eszközök használata mellett hatékonyan és időszerűen lehetne kezelni a piaci problémákat. ${ }^{76}$

\section{Felhasznált irodalom}

Antitrust: Commission accepts commitments by Mastercard and Visa to cut inter-regional interchange fees. European Commission, 2019. Elérhető: https://ec.europa.eu/commission/presscorner/detail/en/IP_19_2311 (A letöltés dátuma: 2020. 08. 09.)

Antitrust: Commission imposes interim measures on Broadcom in TV and modem chipset markets. European Commission, 2019. Elérhető: https://ec.europa.eu/commission/ presscorner/detail/en/IP_19_6109 (A letöltés dátuma: 2020. 08. 21.)

Antitrust: Commission consults stakeholders on a possible new competition tool. European Commission, 2020. Elérhető: https://ec.europa.eu/commission/presscorner/detail/ en/ip_20_977 (A letöltés dátuma: 2020. 08. 21.)

Ioannidou, Marian - Julian Nowag: Can two wrongs make a right? Reconsidering minimum resale price maintenance in the light of Allianz Hungária. European Competition Journal, 11. (2015), 2-3. 340-366. DOI: https://doi.org/10.1080/17441056.20 15.1080044

Mandrescu, Daniel: Restrictions of competition by object and multi-sided platforms - insights from Budapest Bank. 2020. Elérhető: www.lexxion.eu/en/coreblogpost/restrictions-of-competition-by-object-and-multi-sided-platforms-insights-from-budapest-bank/ (A letöltés dátuma: 2020. 08. 21.)

Nagy, István Csongor: The New Concept of Anti-Competitive Object: A Loose Cannon in EU Competition Law. European Competition Law Review, 36. (2015), 4. 154-159.

Nagy, István Csongor: Anticompetitive Object/Effect: An Overview of EU and National Case Law. e-Competitions Bulletin Anticompetitive object/effect, Art. Nº 91905 (2019)

Nagy, István Csongor: Are Payment Card Systems' Multilateral Interchange Fees Anticompetitive by Object under EU Competition Law? Competitition Policy International, 2020. június 2. DOI: https://doi.org/10.2139/ssrn.3622215

Antitrust: Commission imposes interim measures on Broadcom in TV and modem chipset markets. (2019) i. $\mathrm{m}$. Antitrust: Commission consults stakeholders on a possible new competition tool. European Commission, 2020. 


\section{Jogforrások}

2015. április 29-i (EU) 2015/751 európai parlamenti és tanácsi rendelet a kártyaalapú fizetési műveletek bankközi jutalékairól

Az EUB C-228/18. sz. Budapest Bank ügyben 2020. április 2-án hozott ítélete [EU:C:2020:265]

Az EUB C-32/11 sz. Allianz Hungária Biztositó Zrt és társai kontra Gazdasági Versenyhivatal ügyben 2013. március 14-én hozott ítélete [ECLI:EU:C:2013:160]

Az EUB C-56/65. sz. Société Technique Minière kontra Maschinenbau Ulm ügyben hozott ítélete [EU:C:1966:38]

Az EUB C-382/12 P. sz. MasterCard és társai kontra Bizottság ügyben 2014. szeptember 11-én hozott ítélete [EU:C:2014:2201]

Az EUB C-49/92 P. sz. Bizottság kontra Anic Partecipazioni ügyben 1999. július 8-án hozott ítélete [EU:C:1999:356]

Az EUB C-194/14 P. sz. AC-Treuhand kontra Bizottság ügyben 2015. október 22-én hozott ítélete [EU:C:2015:717]

Az EUB C-56/65. sz. Société Technique Minière kontra Maschinenbau Ulm ügyben hozott ítélete [EU:C:1966:38]

Az EUB C382/12 P. sz. MasterCard és társai kontra Bizottság ügyben 2014. szeptember 11én hozott ítélete [EU:C.2014:2201]

Az EUB C373/14 P. sz. Toshiba Corporation kontra Bizottság ügyben 2016. január 20án hozott ítélete [EU:C:2016:26]

Az EUB C67/13 P. sz. CB kontra Bizottság ügyben 2014. szeptember 11én hozott ítélete [EU:C:2014:2204]

$\mathrm{Az}$ EUB C209/07 sz. Beef Industry Development Society and Barry Brothers ügyben 2008. november 20-án hozott ítélete [EU:C:2008:643]

AzEUB C307/18sz. Generics ügyben 2020.január30-án hozottítélete [ECLI:EU:C:2020:52]

Az EUB C286/13 P. sz. Dole Food et Dole Fresh Fruit Europe/Bizottság ügyben 2015. március 15-én hozott ítélete [EU:C:2015:184]

$\mathrm{Az}$ [EUMSZ 101. cikkben] és [az EUMSZ 102. cikkben] meghatározott versenyszabályok végrehajtásáról szóló, 2002. december 16-i tanácsi rendelet

Az EUB C179/16. sz. F. Hoffmann-La Roche és társai ügyben 2018. január 23-án hozott ítélet [ECLI:EU:C:2018:25]. Elérhető: http://curia.europa.eu/juris/document/document. jsf;jsessionid=9ea7d0f130d5936ba9f09a32483b96c7cccbf34968cb.e34KaxiLc3eQc40LaxqMbN4PaNuQe0?text=\&docid=198644\&pageIndex=0\&doclang=HU\&mode=req\&dir $=\&$ occ $=$ first\&part $=1 \& c i d=609021$ (A letöltés dátuma: 2020 . 08. 25.)

COMP/29.373 - Visa International

COMP/39.398 - Visa MIF

A Bíróság 2006. július 13i Manfredi és társai ítélete C295/04-C298/04 [EU:C:2006:461]

A Törvényszék T472/13 sz. Lundbeck ügyben hozott ítélete [EU:T:2016:449]

A Törvényszék T-111/08 sz. MasterCard és társai kontra Bizottság ügyben 2012. május 24-én hozott ítélete [EU:T:2012:260]

A Gazdasági Versenyhivatal 2009. szeptember 24-én kelt Vj-18/2008/341. számú határozata 
A Gazdasági Versenyhivatal Elnökének és a Gazdasági Versenyhivatal Versenytanácsa Elnökének 11/2017. közleménye

Kokott főtanácsos véleménye [ECLI:EU:C:2020:428] Elérhető: http://curia.europa. eu/juris/document/document.jsf?text=\&docid=226985\&pageIndex=0\&doclang=EN\&mode $=1$ st \&dir $=\& o c c=$ first\&part $=1 \&$ cid $=14763467$ (A letöltés dátuma: 2020. 09. 09.)

Sainsbury's Supermarkets Ltd (Respondent) v Visa Europe Services LLC and others (Appellants) Sainsbury's Supermarkets Ltd and others (Respondents) v Mastercard Incorporated and others (Appellants). 17 June 2020. Elérhető: www.supremecourt. uk/cases/docs/uksc-2018-0154-judgment.pdf (A letöltés dátuma: 2020. 09. 09.)

https://www.gvh.hu/dontesek/versenyhivatali_dontesek/dontesek_2008/6225_hu_ vj-0182008341 (A letöltés dátuma: 2020. 09. 09.)

Michal Bobek főtanácsnok C228/18. sz. ügy kapcsán 2019. szeptember 5-én ismertetett indítványa, [EU:C:2019:678]. Elérhető: http://curia.europa.eu/juris/document/ document.jsf;jsessionid=DE6D395AB586DC6472A36250672BAAC5?text=\&do$\mathrm{cid}=217497$ \&pageIndex $=0$ \&doclang $=\mathrm{HU} \& \operatorname{mode}=1$ st $\& \operatorname{dir}=\&$ occ $=$ first $\&$ part $=1 \&$ cid=16070609 (A letöltés dátuma: 2020. 09. 09.) 